\title{
Enhancing Students' English Speaking Skills Through Web-Based Teaching
}

\author{
Irfan Suryana, Vicky Hidantikarnillah, Ikmi Nur Oktavianti \\ English Language Education, Ahmad Dahlan University \\ Email: hi.irfansuryana@gmail.com
}

\begin{abstract}
Teachers play a very important role in the teaching and learning process. They should utilize effective strategies that are included in classroom management. In this digital era, the teachers should adjust their methods in delivering or explaining the materials for the students. One of the technology is the web. This study is different with previous studies because the aim of this study is to investigate the teacher's perceptions of using the web to enhance students' English-speaking skills while the previous studies focus on the use of media to improve students' English-speaking skills such as the use of YouTube video, the use of pictures, animation movie, hand puppet show, and the use of Skype and WhatsApp. This study was under phenomenological qualitative research and characterized by an interdisciplinary approach, especially education and technology. The direct personal interview was utilized to obtain the information from the teacher. The survey encompasses twelve questions that become different categories and was done in eight grades of class B in SMP Negeri 3 Pleret. The results showed that teaching speaking using the web can effectively enhance the students' English-speaking skills and the students give positive reactions regarding this method.
\end{abstract}

Key words: Technology, Education, Classroom Management, Speaking Skills, Web, Web-Based Teaching

\section{INTRODUCTION}

Being an effective teacher is required in this digital era and it should become the central principle that every teacher has in the classroom. As we know, teachers have direct influence over the success or failure of the students. Therefore, they should use responsible and effective strategies in order to collect the students' minds in accepting new knowledge and the teacher also should apply classroom management strategies. Classroom management can be defined as a kind of management that has got to do with the course of action and approaches additionally to instructional techniques which are utilized by the teachers to stay track of the learners and point their performance and learning activities (Kemp 2018). Classroom management deals with a good sort of skills and techniques that the teachers utilize to convince that their classroom runs smoothly, without disruptive behavior from the students. The teachers hope that they will keep students organized, 
orderly, focused, attentive, on task, and academically productive during the learning process in the class (Mulvahil 2018). Classroom management comprises techniques and attitudes in which the teachers manage their classroom situation in order that a student learning can be achieved effectively due to the lack of student misbehavior. There are some goals of classroom management. These goals are to make a successful learning environment, to create the condition in which the learning can be supported and facilitated, to maximize student learning, to support and build students' self-control by promoting positive student achievement and behavior. Specifically, classroom management's principal goal is to make the perfect classroom via the effort of the teacher and also the student training (Tracy 2018).

Classroom management within the English Second Language (ESL) or English Foreign Language (EFL) is often challenging sometimes due to variety of features in English classroom management. There is a main element of classroom management which stays an equivalent and it is known the desire to speak in English. For instance, students are difficult to participate within the classroom because they do not want to make an error. To beat this problem, the teachers can give an example by using the students' native languages. Teachers are bound to have some errors. This is done in order to show the students about the willingness to form mistakes. This classroom management method should be utilized with care because probably some students will wonder at their own learning capabilities regarding the teacher. Another problem can be students enforce translating every word. To unravel this problem, the teachers can take a text with some nonsense words and they will utilize this text for instance in how they will notice common meaning without having to precisely realize each word (Beare 2017).

In order to achieve the goal of classroom management easily, the teachers should consider about the technology that can be used as their strategy of the teaching learning process. As we know, technology is the driving force behind every area of life today. Technology plays a main part in societies and it is often utilized for several factors of lifestyles. For example, many of us utilize technology to do activities and work such as checking out employment, accomplishing business transactions, or collecting information. Technology also can aid in advancing the curriculum. There are many technological gadgets which will aid people's lives easier on a dayto-day basis, like computers, laptops, smartphones, and tablets. Many of us utilize technology, including young children. It is no secret that technological teaching strategies have successfully been utilized in many institutions round the world (Gunada 2018). The development within technology of interactive media has created an improvement within the utilization of technology in learning situations (Fralinger and Owens 2009). Technology supplies teaching and learning with plenty of applications. As we all know, right now students are the members of the digital generation so that they are usual with technology. By using technology, the teachers can finish many jobs more efficiently and effectively. Utilizing web in education features a positive impact in classes (Gunada 2018).

Using internet in teaching and learning process is needed for the teachers in this digital era in order to 
adjust with the improvement of technology and the students' condition who have been familiar with the internet. There are many types of educational media. Educational media is any kind of media that is used to educate students on certain subject. Educational media can be utilized at home or in the classroom and it covers a numerous number of various types of media. Media can be categorized as text, image, video, and audio (Reference.com, n.d.). In addition, there are some classification of educational media such as (1) printed media such as journals, books, newspapers, magazines, textbooks, and workbooks (2) non-printed media such as projected and nonprojected media, (3) electronic media such as audio, visual, audio-visual, projected, and non-projected media (O.D. and E.I. 2014). Electronic media have different types as well including magazines, newspaper, radio, television, traditional media, internet, and so on (Ghanta 2012). One thing that uses internet is web. Web is something which was invented by Tim Berners-Lee in 1989 (Yamato 2017). Web or Word Wide Web is known as a blend of all of resources and users on the internet which are utilizing the HTTP or Hypertext Transfer Protocol (Rouse 2017). Web itself can be utilized for teaching and learning process.

Web-based teaching deals with creating connections. It can be connecting the students to resources round the world, blending various materials such as music, submission, words, explanation into one demonstration, gathering certain data from many sources. Web-based teaching can enable the students to form their own connections because the students can download and utilize the materials on the web for their learning process or they can construct web documents as a part of their assignments (Wasim et al. 2014). Therefore, technological tools are considered as ways of helping students in learning technology skills and also English language skills, including speaking skills (Kasapoglu-Akyol 2010).

Speaking is deemed as the most important skills in order to be enlarged and improved for communication (Leong and Ahmadi 2017). Speaking skills can be categorized as a prolific skill and it cannot be set apart from listening. Once people speak, they build the meaningful text. Within the nature of communication, people will understand that there are the speaker, the listener, the message, and the feedback when they communicate. Also, speaking cannot be set apart from pronunciation because it supports the students to find out the English sounds (Media 2013). Speaking itself is an action of creating the vocal sounds. People believe that speaking is to converse or express one's thoughts and feelings in speech. Talking often implies delivering certain information. While speaking skills are the talents that give people the power to speak effectively. Best speaking shows our skill in English (Aswad 2017). These skills permit the speakers to convey his message during a passionate, thoughtful, and convincing manner. Speaking skills also aid to assure that an individual will not be misunderstood by those who are listening (Amir 2013). There are four speaking skills that good speakers must have. These are fluency, vocabulary, grammar, and pronunciation (Binus University 2018).

There are many reasons why speaking skills are really important for each individual. Without speech, people will not be able to communicate 
with each other. The significance of speaking skills hence is gigantic for the languages learners around the world. Without speaking, a language is lessened to a mere script. The utilization of language is an occupation that happens within the constraint of the environment. People utilize language during a sort of conditions. A speaker can be considered as an effective speaker if the speaker can obtain the eye of the audience and hold it until the completion of the message. Speaking skills are important for career success but never limited to one's professional aspirations. Speaking skills also can improve individual's personal life (Qureshi, n.d.).

This study is really important to do because this study is to investigate the teacher's perceptions of using the web to enhance students' English speaking skills so that the other teachers can obtain the depiction about utilizing web in the classroom and they can understand about the effectiveness and the challenges of using this kind of technology in teaching and learning process.

\section{REVIEW OF LITERATURE}

Many researchers have investigated regarding the influence of media to enhance English Speaking skills. Firstly, Gunada investigates about the use of YouTube video to improve student's speaking skills. The aim of his study is to show the theoretical perspective regarding YouTube video as an IT-based media in order to enhance students' English speaking skills. He states that some previous study have proved that using YouTube videos can improve the important aspects in speaking skills such as fluency, vocabulary, pronunciation, and grammar (Gunada 2018). Secondly, Nurdini observes regarding the use of picture to improve students' English speaking skills. Her purpose is to investigate the use of pictures to teach English speaking or conversation interestingly and efficiently. She emphasizes that the utilization of images has enabled students to practice speaking English regularly even when they are in outside the class and to memorize the subjects better and to enhance their English speaking skills (Nurdini 2018). Thirdly, Fauza and her friends research about using hand puppets show media to improve students' English speaking skills and motivation. Their aim is to observe whether the use of hand puppets show media enhances the students' English speaking skills and motivation in learning English or not. They emphasize that the use of hand puppets media in teaching English speaking skills is more effective to improve the students' English speaking skills than teaching speaking without using hand puppet media (Fauza, Usman, and Muslem, n.d.). Fourthly, Rahayu and Erippudin investigate about improving students' English speaking skills through animation movie. They did the research at sixth grade SDN 002 Ujungbatu, Rokan Hulu, Riau (Rosdalina, Pipit Rahayu 2014). Fifthly, Lestari observes regarding improving speaking skills by vlog or video blog. Her purposes of the research are to know how the students' perspective on the use of video blog to enhance speaking skills and to study regarding what students' strategy in using video blog in order to enhance speaking skills. (Lestari 2019). Mustafa observes about the impact of YouTube, Skype, and WhatsApp in improving EFL learners' speaking skills. His aim is to come out with constructive recommendations for students, teachers, and educationists to enhance the processes of teaching and learning spoken English. 
The result of his research is that the social media networking has a great impact on speaking (Nasr and Mustafa 2018).

There are some webs that can be utilized to teach English speaking skills. The first is EnglishClub. The address of this website is www.englishclub.com. This is a kind of free and independent website that is created in order to aid the English learners through online and the founder of this precious website is Joe Essberger. EnglishClub itself comes from England and it is written specially in British English. This website allows the users to make their own English page with many features, such as blogs, photos, videos, music, groups, and also friends. This can be utilized to examine the users' level in English and gain assessment with the English grammar. The users can learn English grammar, vocabulary, and pronunciation. They can play English games and do the English quizzes online as well. They can chat in English with the other students and teachers. Moreover, the students can know the schools in which they can learn English at home or abroad and they can obtain penpals for English practice. In addition, EnglishClub has many various principal categories that the users can utilize them easily. The categories are (1) lessons which include English Grammar. English Vocabulary, and English Pronunciation; (2) interactive which includes Grammar Help, Play ESL Games, Discuss at ESL Forums, Chat in ESL hat, Listen to the News in English, MyEnglishClub, and Learning English Video Project; (3) Special Interest which includes Business English. This website is also completed with many features, such as Learn English, Teach English, MyEnglishClub, Games and eBooks, Grammar, Vocabulary, Pronunciation,
Listening, Speaking, Reading, Writing, and many more.

The second website is ESL-LAB or Randall's ESL Cyber Listening Lab. The address of this website is www.esllab.com. The most important figure of this website and the one who created the website is Randall Davis. He graduated with an undergraduate degree in Spanish education more than 30 years ago and followed by a master's degree in TESL. There are many listening activities in the website, such as Easy, Intermediate, Difficult, Basic English Quizzes, Academic Listening, English Culture Videos, Vocabulary Quizzes, Randall's Favorites, Self-Study Guide, and ESL Study Handouts.

\section{METHOD}

To collect the data, we used qualitative method by using direct interview. There were some steps before we interviewed to the subjects. Firstly, we investigated what kinds of school that we wanted to observe. Secondly, we arranged 12 questions that we would be asked to the subjects. Thirdly, we determined the time and the place for the interviewee. Fourthly, we summed up each answer from the subjects.

\section{Research Design}

This study is designed by using qualitative research. Qualitative research emphasizes on the understanding a research query as a humanistic or idealistic approach. Qualitative method is employed in order to know people's beliefs, experiences, attitudes, behavior, and interactions. This research generates non-numerical data and the mixing of qualitative research into the 
intervention studies may be a research strategy that is obtaining increased attention across disciplines (Pathak, Jena, and Kalra 2013).

To do the research, we used phenomenological qualitative research. A phenomenology is a kind of an approach to qualitative research. This deals with the commonality of a lived experience within a certain group. The elemental purpose of the approach is to reach an outline of the subject of the actual phenomenon (Creswell 2007).

\section{Subject}

The subject of the study was actually two English teachers but it turned that only one teacher who utilized web as media to teach English speaking skills. Therefore, we decided to gain deep information from one teacher. She teaches the students of eight grades of class B in SMP Negeri 3 Pleret and she has been teaching there since 2018. There are 39 students which encompasses 17 males and 22 females. The address of the school is Jembangan, Segoroyoso, Pleret, Segoroyoso II, Segoroyoso, Pleret, Bantul, Special Region of Yogyakarta, Indonesia. We chose her as our subject because she is an English teacher in the school.

\section{Instruments}

We utilized a direct personal interview that was held in 14 December 2019 in the hall of campus 2 of Ahmad Dahlan University. A direct personal interview forms a face to face with the informants (persons from whom the information is to be gained) in the process of collecting the data. The obtained information is considered as more accurate information because the interviewer can clear the doubts of the informants regarding specific questions and thus gain the right information. This method also supplies the scope for obtaining supplementary information from the informant because when interviewing it is possible to ask some supplementary questions which can be of greater use later (A. Sulthan 2019). Personal interview method needs an individual referred to as the interviewer asking some questions commonly during a face-to-face communication to the certain person or persons. At times the interviewee can also ask certain questions and therefore the interviewer responds to those, but usually the interviewer initiates the interview and gathers the information (Wisdomjobs.com, n.d.).

There are twelve questions that we ask to the teacher. These questions include (1) How do you apply classroom management during teaching and learning process? (2) How do you implement web in teaching and learning process? (3) What are the things that must be prepared by the teacher in teaching using web? (4) What are the things that must be prepared by the students in learning using web? (5) Why do you choose teaching using web to enhance students' English speaking skills rather than the other media such as radio and YouTube? (6) What are the problems in teaching using web? (7) How do you cope the issues? (8) What do you do if there is a student who disturbs during the teaching and learning process? (9) What webs do you utilize to enhance students' English speaking 
skills? (10) Is this method effective for improving students' English speaking skills? (11) How do you examine the students after learning using web in purpose to enhance students' English speaking skills? (12) How do the students react or perceive during learning using web?

\section{Data Analysis}

After gathering the data, we summed up each answer and entered them into the category which was the description of the questions themselves.

\section{RESEARCH FINDINGS AND DISCUSSION}

\section{Research Findings}

The study sample encompassed two English teachers but we decided to gain deep information from only one teacher because another teacher did not use media such as web to teach English speaking skills. The data collection was done through a direct personal interview. The data gained in this study were observed by using qualitative methodology. Especially, we examined the subject about the use of web in order to enhance English speaking skills.

\section{Category 1. The Utilization of Classroom Management}

When the teacher was asked about the utilization of classroom management, she described about the arrangement in teaching in the class, starting when she enters the class, gives the material, and closes the meeting. The purpose of this category is to know what the teachers does in managing the classroom during teaching and learning process.

"When I enter the class, I always invite the students to start the lesson by praying Let's start our study today by reciting basmallah. Then I greet the students such as Good morning students! How are you? After that I invite the students to initiate the lesson (Okay, today's lesson is talking about conversation. Are you ready to start?) I start to explain the material, give the example, try one of the students to stand up in front of the class and write on the whiteboard related to the material. Moreover, I also give the assignments for the students with the limited time. I endeavor to pay attention to each student. For instance, I ask one by one of the students regarding their understandings about the material. Then, I give the students the opportunity to ask about the material if there is still something that they have not understood yet. If the time is up, I close the meeting by inviting the students to say hamdalah together. I also always give the student homework to ensure that they truly understand about the material."

It showed that she manages the class systematically when she teaches the students. We think that it is a really good arrangement because the teacher can manage the classroom starting from she enters the class, teaches the students regarding the material, until closes the meeting by saying hamdalah.

\section{Category 2. The Implementation of Web}

In category 2 , we asked the teacher about the implementation of web in teaching speaking 
skills. The aim of this category is to know about the implementation of web-based in teaching speaking skills. She explained how she implements web in teaching speaking skills as follow:

"I ask the students to access certain webs as reference for study"

The teacher's answer showed that she asked the students to access some specific webs to support the teaching and learning process in order to enhance students' English speaking skills.

\section{Category 3. Teacher's Preparation}

In this section, we attempted to dig in more about preparation that the teacher does in teaching using certain webs. The purpose of this category is to know what the things that the teacher needs to teach English speaking skills using specific webs. She conveyed her answer about the question as follow:

"Firstly, I explain about the use of the web as the learning media. Then, I describe the content of the web. After I explained it, I ask the students to comprehend the web. Secondly, I prepare the material for speaking and debating. Then I prepare the availability of wi-fi. Then I ensure that all of the students bring tab or ipad. After that, I start the lesson."

From her answer, we can know that to teach English speaking skills, the teacher should introduce the specific webs that will be used as learning media, such as the function of the web and the use of the web. The teacher also needs to make sure whether the students have understood regarding the web or not. This thing is done in order to all of the students can follow the lesson. Moreover, before the lesson is initiated, the teacher should ensure the equipment or the facilities so that the lesson will run well.

\section{Category 4. Students' Preparation}

This section tried to gain the information about the students' preparation in learning English speaking skills through certain webs. The aim of this category is to know what things that the students need in following the lesson using web. The teacher's answer can be seen as follows:

"Of course, the students must bring the books regarding the lesson and prepare the equipment to access the web, such as tab, ipad, or laptop"

Her answer depicts that following the lesson using web, the students must prepare the books and also tab, ipad, or laptop. Then, we asked again to the teachers if there are some students who do not have these things, what will the teacher do? The teacher said that those students can utilize the provided computers in the school. We can assume that the teacher really makes use of the technology in teaching and learning process.

\section{Category 5. The Reason of Choosing Web in Teaching Speaking Skills}

This category emphasizes on the reason of choosing web in teaching speaking skills. The purpose of this category is know deeply 
regarding the teacher's reason why she utilizes web in teaching speaking rather than the other media, such as radio and YouTube. The teacher told her answer as follows:

"Because by using web the students will study as I guide them in teaching and of course I adjust the material with the competency of the class. Another reason why I use web is I perceive I am capable of teaching using web and the students obtain more interested at the lesson if they use web. Moreover, the students will be more focused on the material because there is only one source or one channel. If I use YouTube in teaching speaking, the students will not really focus because YouTube has lots of channels, even they can open another channel outside the material."

We can know that the teacher utilized web because of many reasons. Firstly, the teacher thought that it is easy to utilize web in teaching. Secondly, the teacher contended that the students are more interested in following the lesson using web rather than the conventional way. Thirdly, the teacher believed that she can explain and deliver material effectively by using web rather than the other media such as radio and YouTube because the students can only focus on the material without any destructive things.

\section{Category 6. The Issues in Teaching Using Web}

In this category, we wanted to gain information about the problems that occur during the teaching and learning process using web. The aim of this category is to know what kinds of the issues that happen in teaching speaking using web. The teacher statement can be seen as follows:

"There are some problems that I face in teaching using web, such as the internet connection. Sometimes, the internet connection is very slow so that it hampers the process of accessing the web. When there is a problem with the internet connection, the study will be not effective. Even one day I experienced this problem. In that moment, the duration of study was 90 minutes but there was no practice at all because of the problem of the internet connection so that the time was up and I could only deliver the material without any practices. Another problem is sometimes there are still some students who have not understood yet about the use of the web."

After asking her about the issues of teaching using web, we can know that there are two main problems in teaching using web. These problems are about the speed of the internet connection and the understandings of the students regarding the use of the web.

\section{Category 7. The Solution of the Issues}

In order to know about the solution for the problems, we asked the teacher how she unraveled the problems. The purpose of the analysis is to know exactly about the solutions. Her answer can be seen as follows:

"In order to cope the problems, I will give more description to the students and even I play the games with them so that they will not be bored when the problem of the speed of the internet connection happens. If there are some students 
Irfan Suryana, Vicky Hidantikarnillah, Ikmi Nur Oktavianti

who have not understood yet about the web, I usually walk between among the students when explaining the material and I ask them one by one regarding their understandings. Sometimes, some students say that they have already understood what I explained to them but in the fact they have not. To troubleshoot the problem, I have to be active to pay attention to each students. Then, if I found some, I will explain them from the beginning slowly but surely"

Her answer showed that she always found the ways to manage the class even if the problems come. For example, if there is a problem with the internet connection, she will explain more regarding the material so that the students can gain more information about the lesson. She also utilizes the games so that the students will not feel boring. In addition, she always attempts to ensure that all of the students understand about the material. If there are some students who have not understood yet, she will explain again to them slowly.

\section{Category 8. Teacher's Treatment in Handling Disturbance}

This category focuses on the teacher's treatment if there are some students who disturb during the teaching and learning process. The aim of this category is to know about what the teacher will do to handle the disturbance from the students. Her answer can be seen as follows:

"Of course, I will warrant them and if the students keep disturbing the class, I will advise them. If they keep doing the disturbance, I will ask them to go out from the class and
I will note their names, then I will give the notes to the counseling room. However, alhamdulillah, up to now there are no students who I ask to go out from the class because they become obedient after I advice them"

From this category, we can know about the teacher's treatment in handling the disturbance. It depicts the steps of handling the disturbance, starting from giving a warning, advising, and asking the students to go out from the class. However, she highlighted that it is enough for her to advice the students because they become obedient again and do not disturb the class anymore.

\section{Category 9. Webs in Teaching Speaking Skills}

In this category, we asked about the webs that the teacher utilizes in teaching speaking. The purpose of this question is to know certain webs that are appropriate in teaching speaking. She told the answer:

"There are some webs that I use in teaching speaking. These webs are www.englishclub. com and www.esllab.com."

Through this category, we can know three webs that can be utilized in teaching speaking. These webs are www.englishclub.com and www. esllab.com.

\section{Category 10. The Effectiveness of the Method}

This section attempted to obtain the teacher's perception about the effectiveness in 
using web in teaching speaking. The aim of this section is to know whether using web in teaching speaking is effective to enhance students' English speaking skills or not. Her answer can be seen as follows:

"I believe that it is really effective because using web in teaching speaking is more interested and not boring."

We can conclude that teaching speaking using web can make students more interested in following the lesson. They will also not be boring during the learning process. If the students can follow the material in an optimal fashion and they can study seriously, their speaking skills will improve as well.

\section{Category 11. The Examination}

In this category, we asked the teacher about the examination after accomplishing the lesson using web. The purpose of this category is to know how the teacher examines the students after finishing the lesson. Her statement can be seen as follows:

"During the teaching and learning process, I usually use two languages which are English and Bahasa Indonesia so that the students can comprehend about what I mean. Therefore, I also test them regarding my speaking in the class. In addition, when the meeting will end, I always ask the students about certain sentences or words which have been learn on the day. In that moment, they can speak what they have already learnt."

From the category, we can know that the teacher examined the students' understanding about what she talked about in the class. She also examined the students about their vocabulary that they have already learnt. As we know, vocabulary is one of important factors in speaking.

\section{Category 12. The Student's Reaction}

The last category is about the students' reaction. The purpose of this category is to know deeply about how the students react or perceive in learning speaking using web. Her answer can be seen as follows:

"Their reactions are various. Some of the students are really enthusiastic in learning speaking using web but some of them are lazy because even reject learning speaking using web because they have not understood yet fully about it. However, the students want to keep learning so far and even they enjoy learning using the web. Many of them feel happy because there are many videos in the web which show how to speak English correctly and there are native speakers who practice speaking. Therefore, the students become more interested in learning speaking."

Through this category, we can conclude that the students' reactions about learning speaking using web are positive. Even though some of them seem lazy and even rejected, eventually they can follow the lesson. They can finally obtain the interest in learning using web because the webs provide English speaking videos and native speakers as well so that they can imitate them. 


\section{Discussion}

After gathering the data and analyzing the research findings, we can summarize that utilizing specific webs such as www.englishclub.com and www.esllab.com in teaching English speaking is indeed effective for the students to enhance their speaking skills. However, the teacher should have already prepared about some things including the material before she is directly going to teach using web. This will lead her to gain an effective teaching. There are some factors that can aid in the applying of effective teaching and learning. These factors are teaching resources and materials. There are many various teaching resources and materials that can be implemented in the lessons, such as textbook, audio visual tools, task sheets, videos, handycams, data management software, teaching software, and internet (Kamaruzaman and Akbar 2014). Preparation and planning are two crucial aspects of effective teaching. If there is a lack of them, there will be a failure of teaching and learning process (Meador 2019). Not only teacher but also the students need to prepare the lesson before they are going to follow it. In teaching and learning process, the students must understand the importance of being prepared for the lesson. It is believed that a short amount of time which is spent to preview the day's material before the class will save hours of ineffective study later (Sickler 2017).

Moreover, learning through digital media, including web is considered as an interesting thing for the students rather than they have to learn using the conventional ways. Digital learning tools and technology can make students more engaged and more interested in learning process regarding a certain topic of study. Now digital learning is deemed as a more interactive and memorable method than voluminous textbooks because it provides a better context and can grab the students' intention rather than traditional education methods (Digital 2017). Also, if the students utilize certain webs in learning process, they will be more focused than if they utilize another media such as YouTube. YouTube indeed has many advantages for learning but it has also some drawbacks, for instance the advertisements. If they learn material from YouTube, it is hard for them to focus on the material that is being showed on the video because videos on YouTube often have advertisements and some of them can be very lengthy without a choice to skip .These advertisements can be probably not appropriate for the material that is being taught and learnt. Moreover, the students can access another videos easily and some contents of the videos may not be suitable for the age group of the students (Gaille 2017).

Even though using web for teaching speaking skill is not always perfect because the problems can happen during the teaching and learning process, such as the issue of the internet connection and the disturbance from the students, the teacher can find the solution or she can troubleshoot the problems. This is a sign that the teacher should have problem solving skill in the classroom. As we know, teaching is a practical activity. Therefore, the teacher should have one of the fundamental competences which is known as problem solving skill. Sometimes the teaching process does not run well because the challenges often come and the teacher requires 
to learn to unravel with her current problems (Orgoványi-Gajdos 2016).

In order to test the students' understandings regarding the material, the teacher needs to examine them after accomplishing the lesson. This can be a factor of evaluation. Evaluation is one of very important components in the teaching and learning process because it can aid the teacher and the students to enhance teaching and learning, form the values of assessment, educational status, and achievement of the students, and also it can help to contribute the formulation of objectives, designing of learning experiences, and assessment of the students performance (M, n.d.).

In addition, from the research findings it can be known that the students give positive reactions in learning speaking using web and this is very good for them because if the students enjoy learning something, they can participate fully regarding the topic. When the teacher utilize the activities that make learning engaging and fun, the students will be more willing to participate and take risks during the teaching and learning process (American English 2016)

This result can be a suggestion for the further research in order to investigate the use of specific web in speaking skill, the use of webs in a larger case study, or observe the utilization in the other English skills, such as listening skill, reading skill, and writing skill.

\section{CONCLUSION}

As we know, the development of technology has been influencing many factors in this life, including in education so that the teacher should be effective in this digital era. The classroom management assists the teacher how to manage the class because it concerns with skills and techniques or methods that the teacher utilize in the classroom in order to make a successful teaching and learning.

The teacher can utilize various technologies to achieve the aim of the classroom management easily (Halik et al. 2019). One of them is web which includes as educational media. This study emphasizes on the use of web in teaching speaking. Speaking skill is the second of the four language skills, such as listening, speaking, reading, and speaking skills. Speaking plays an important role in this life, such as in order to deliver one's thoughts, opinions, and feelings, so that the teacher should consider the best method to teach speaking. The study is done in SMP Negeri 3 Pleret. There are some webs that are utilized in teaching speaking such as www. englishclub.com and www.esllab.comand these webs make the students more interested in learning speaking rather than the traditional teaching web. Therefore, teaching using web is really effective in order to enhance students' English speaking skills.

To teach English speaking skills, the teacher should introduce the certain webs that will be utilized as learning media, such as the function of the web and the use of the web. Also, the teacher needs to make sure the students' understanding regarding the web. This aspect is done in order to all of the students can follow the lesson. Next, before the lesson is started, the teacher should ensure the equipment or the facilities so that the lesson will run 
well. Therefore, teaching using web is really effective in order to enhance students' English speaking skills.

\section{REFERENCES}

A Sulthan. 2019. "Direct Personal Interviews - Methods of Primary Data Collection.” SAR Publisher. https:// www.sarpublisher.com/direct-personal-interviewsmethods-of-primary-data-collection/.

American English. 2016. “Teacher' S Corner." In American English. americanenglish.state.gov. https:// americanenglish.state.gov/resources/teachers-cornermaking-learning-fun.

Amir, Hina. 2013. "Speaking Skills." In . https://www. slideshare.net/zeal_eagle/speaking-skills-24884424.

Aswad, Muhammad. 2017. "Is It Truly Improvisational Exercise Push Students' Speaking Ability." EDUVELOP (Journal of English Education and Development) 1 (1): 9-17.

Halik, Abdul, St Wardah Hanafie Das, Muhammad Aswad, M. Syakir Rady, Muhammad Siri Dangnga, and M. Nasir S. 2019. "Empowerment of School Committee in Improving Education Service Quality at Public Primary School in Parepare City." Universal Journal of Educational Research 7 (9): 1956-63. https://doi.org/10.13189/ujer.2019.070915.

Beare, Kenneth. 2017. "Classroom Management."

Binus University. 2018. “The Four Speaking Skills.” In , 1-3. https://english.binus.ac.id/2018/10/11/thefour-speaking-skills/.

Creswell, John W. 2007. Qualitative Inquiry \& Research Design: Choosing Among Five Approaches. Thousand Oaks: Sage Publications.

Digital, Panworld Education. 2017. "BENEFITS OF DIGITAL LEARNING OVER TRADITIONAL.”

Fauza, Hayatun, Bustami Usman, and Asnawi Muslem. n.d. "Improving Students' Speaking Skill and Motivation by Using Hand Puppets Show Media," 216-28.

Fleck, Bethany K B, Lisa M Beckman, Jillian L Sterns, and Heather D Hussey. 2014. "YouTube in the
Classroom : Helpful Tips and Student Perceptions" 14 (3): 21-37.

Fralinger, Barbara, and Russell Owens. 2009. "You Tube As A Learning Tool" 6 (8): 15-28.

Gaille, Brandon. 2017. "11 Pros and Cons of Youtube in Education.” https://brandongaille.com/11-pros-andcons-of-youtube-in-education/.

Ghanta, Chandra Shekhar. 2012. "Coverage of Health Information in Electronic Media - A Study." Journal of Arts, Science \& Commerce 2 (2): 95-99.

Gunada, I Wayan Sastra. 2018. "Using YouTube Video; An IT-Based Media to Improve Students' Speaking Skill," no. June: 0-9.

Kamaruzaman, Syed, and Muhammad Akbar. 2014. "Teachers Planning and Preparation of Teaching Resources and Materials in the Implementation of Form 4 Physical Education Curriculum for Physical Fitness Strand." Turkish Journal of Sport and Exercise 16 (1): 67-67. https://doi.org/10.15314/ tjse.201416165.

Kasapoglu-Akyol, Pinar. 2010. "Using Educational Technology Tools to Improve Language and Communication Skills of ESL Students." NovitasRoyal 4 (2): 225-41.

Kemp, Craig. 2018. "Top 10 Technology Classroom Management Strategies That Work Technology as a Classroom Management Strategy Why Should Teachers Use These Strategies ? Technology Teaching Strategies That Work 1. Use Technology to Search the Internet 2 . Use Microsoft Suite."

Leong, Lai-mei, and Seyedeh Masoumeh Ahmadi. 2017. "An Analysis of Factors Influencing Learners' English Speaking Skill." International Journal of Research in English Education, 34-41.

Lestari, Novita. 2019. "Improving the Speaking Skill by Vlog ( Video Blog ) as Learning Media : The EFL Students Perspective Improving the Speaking Skill by Vlog (Video Blog) as Learning Media : The EFL Students Perspective Novita Lestari” 9 (1): 915-25. https://doi.org/10.6007/IJARBSS/v9-i1/5490.

M, Disha. n.d. "Evaluation in Teaching and Learning Process.” In Your Article Library. yourarticlelibrary. 
com. http://www.yourarticlelibrary.com/statistics-2/ evaluation-in-teaching-and-learning-processeducation/92476\#Need_and_Importance_of_ Evaluation.

Meador, Derrick. 2019. "Strategies for Teachers : The Power of Preparation and Planning," 4-6.

Media, Zaky. 2013. "Definition of Speaking Skill (Skripsi Pendidikan Bahasa Inggris Gratis ).” In . http://www. zakymedia.com/2013/06/definition-of-speakingskill.html.

Mulvahil, Elizabeth. 2018. "What Is Classroom Management?"

Nasr, Elhadi, and Elhadi Mustafa. 2018. “The Impact of YouTube, Skype and WhatsApp in Improving EFL Learners â€ $€^{\mathrm{TM}}$ Speaking Skill.” International Journal of Contemporary Applied Researches 5 (5): 18-31.

Nurdini, Rahmi Aulia. 2018. "The Use of Picture To Improve Students' Speaking Skill in English.” IJET (Indonesian Journal of English Teaching) 7 (2): 15762. https://doi.org/10.15642/ijet2.2018.7.2.157162.

O.D., Omodara, and Adu E.I. 2014. "Relevance of Educational Media and Multimedia Technology for Effective Service Delivery in Teaching and Learning Processes" 4 (2): 48-51.

Orgoványi-Gajdos, Judit. 2016. “Teachers'professional Development on Problem Solving: Theory and Practice for Teachers and Teacher Educators." Teachers' Professional Development on Problem Solving: Theory and Practice for Teachers and Teacher Educators, no. October: 1-134.

Pathak, Vibha, Bijayini Jena, and Sanjay Kalra. 2013. "Qualitative Reseacrh." Perspectives in Clinical Research 4 (3). https://doi.org/10.4103/22293485.115389.

Qureshi, Ishrat Aamer. n.d. "THE IMPORTANCE OF SPEAKING SKILLS FOR,” no. 5655: 1-10.
Reference.com. n.d. "What Is Educational Media ?" In . https:/www.reference.com/world-view/educationalmedia-c0d8b39422120f19.

Rosdalina, Pipit Rahayu, Eripuddin. 2014. "Improving Student's Speaking Skill Trought Animation Movie." Pendidikan 11.

Rouse, Margaret. 2017. "World Wide Web (WWW)." In . https://whatis.techtarget.com/definition/WorldWide-Web.

Sickler, Angela Zanardelli. 2017. "Study Strategies for Before, During, and After Class." In Faculty Focus. facultyfocus.com. https://www.facultyfocus.com/ articles/teaching-and-learning/study-strategiesclass/.

Tracy, Johnston. 2018. "Author : Tracy Johnston.”

Wasim, Javed, Sunil Kumar Sharma, Imshad Ahmad Khan, and Siddiqui Jamshed. 2014. "Web- Based Learning Innovations." International Journal of Computer Science and Information Technologies 5 (1): 5859-64.

Wisdomjobs.com. n.d. "Interview Method Research Methodology." In . Wisdomjobs.com. https://www.wisdomjobs.com/e-university/ research-methodology-tutorial-355/interviewmethod-11489.html.

Yamato, Jen. 2017. "World Wide Web Inventor Tim Berners-Lee : Free the Internet!" In Daily Beast. https://www.thedailybeast.com/world-wide-webinventor-tim-berners-lee-free-the-internet. 